\title{
Forests, people and environment: some African perspectives
}

\author{
${ }^{1}$ Chirwa PW ${ }^{2}$ Larwanou M and ${ }^{3}$ Kowero G
}

\author{
Guest Editors \\ ${ }^{1}$ Professor Paxie W Chirwa, Forest Socio-ecologists and Agroforestry Scientist \\ ${ }^{2}$ Professor Mahamane Larwanou, Forest Ecology Management and Agroforestry Scientist \\ ${ }^{2}$ Professor Godwin Kowero, Forest Economics and Policy \\ ${ }^{1}$ University of Pretoria, Forest Science Postgraduate Programme, 5-15 Plant Sciences Complex, \\ Pretoria, South Africa \\ Email: paxie.chirwa@up.ac.za \\ ${ }^{2}$ African Forest Forum (AFF), C/o World Agroforestry Centre (ICRAF), United Nations Avenue P.O. \\ Box 30677 - 00100, Nairobi, Kenya \\ Emails: G.KOWERO@CGIAR.ORG; M.Larwanou@CGIAR.ORG
}

\begin{abstract}
Forests in Africa support the livelihoods of millions of people through provision of: timber and nontimber forest products; food and nutrition; energy; and payment of environmental services. However, mismanagement of forests has resulted to deforestation and forest degradation thereby contributing to the increased emission of carbon dioxide into the atmosphere. This special issue highlights some of the research presented at a pre-congress workshoporganized by the African Forest Forum and partners at the 2015 World Forest Congress (WFC). In this issue, the main drivers of land degradation are highlighted visa viz: population growth; agricultural expansion; climate variability; drought and energy needs. Promising traditional management practices are identified including age old farmer managed natural regeneration and enclosures. In addition, research presented indicates that age-old systems such as native non-browse shrubs in Ethiopia are important in that they facilitate regeneration of late successional trees species. Furthermore, opportunities for using forests to mitigate climate change (CC) are highlighted with a case study on the economics associated with carbon markets. Furthermore, the issue highlights the methodological challenges of quantifying carbon in African forests. The effect of climate change on threatened forest species and biodiversity in general is discussed; and the associated human disturbances impacting on the population structure of a threatened species e.g. Afzelia Africana in West Africa is presented. The important role of non-timber forest products in income generation for the rural communities and the associated challenges to commercialization with examples from two important tree species, Shea (Vitellaria paradoxa) and Baobab (Adansonia digitata) is emphasised. Finally, the issue covered people centred approach in tree planting and management where studies demonstrated that there are still problems of poor participation of local communities due to poor implementation of enabling policies, lack of involvement in initial planning and subsequent lack of clear benefit sharing mechanisms.
\end{abstract}

Keywords: African forests, climate change, livelihoods, forest disturbance, natural regeneration

\section{Introduction}

The highest deforestation and forest degradation rates in Sub-Saharan Africa (SSA) occur in the dry

forests and woodlands and Sahel where the pressure for land is continuously increasing due to 
rampant poverty and limited livelihood options. In addition, land and forest tenure and rights of access to forest and woodland resources are either not clearly defined or are non-existent to many people in many parts of SSA (FAO, 2008). The different forest types support many ecosystem services important to the people of Africa and their environment as well as to the global community. According to the Millennium Ecosystem Assessment, ecosystem services are defined as "the benefits people obtain from ecosystems ". These are categorised as: provisioning, regulating, supporting and cultural. In Africa the local communities appear to place more weight on benefits arising from provisioning services like fuelwood, construction materials, water, wild foods, medicines, and fodder for their livestock. In addition, some forests are protected as 'sacred forests', in such a manner they secure the provision of cultural services like spiritual places of worship and reflection to some of the local communities. At the national and sub-national levels, larger societal interests guide the way these ecosystem services are viewed and investments in them are made. For example, socio-economic priorities dictate interests and investments in securing sustainable supplies of raw materials for the timber industry and medicinal plants for pharmaceuticals and hydro power energy; some key provisioning services. Of the cultural services, science, education and recreational experiences, for example through ecotourism are of interest at the national level. The generation of supporting services like soil formation and nutrient cycling, services that help secure the production of all ecosystem services are also of interest at the sub-national and national levels. At the global level most of the national level priority provisioning and cultural services from these ecosystems are of interest and feature prominently in international discourses on environment, and more specifically those on forestry biodiversity. In addition the regulating services like carbon sequestration in order to contain global warming and supply of water are now on top of many agendas globally.

It is therefore very challenging to manage these forests to sustainably supply these ecosystem services at all these levels, principally because some interests conflict at various levels and responsibilities for the different stakeholders are not properly defined and accompanied by requisite resources and accountability mechanisms. Added to these are threats to the forest and tree resources arising from 
adverse effects of climate change, pressures from fairly rapidly growing populations, weak public forest administrations and local communities (two key players in forest ownership and management) that cannot adequately enforce forest laws and regulations in addition to exercising good forest governance, as well as deforestation and forest degradation.

With respect to deforestation, agricultural activities explain about $80 \%$ of deforestation that takes place in Africa. With regard to forest degradation, inappropriate firewood collection and charcoal production account for the largest share (45\%) in Africa, followed by timber harvesting or logging (32\%), while uncontrolled livestock grazing and uncontrolled fires play a minor role of less than $10 \%$ (Hosonuma et al., 2012). As a result, these activities have greatly contributed to the degradation of woodlands and forests in Africa. In addition, these activities contribute to the increased emission of carbon dioxide into the atmosphere as the carbon sink is progressively reduced.

On the other hand, the forestry sector has the greatest mitigation opportunities as net sinks of carbon dioxide and could benefit from resources made available through the global mechanism on Reducing Emissions from Deforestation and forest Degradation (REDD+) as well as from provisions of the Clean Development Mechanism (CDM) of the Kyoto Protocol. The Paris Agreement provides more insights on how to tap into these mechanisms in ways that enhance the functions of the forest ecosystems as carbon sinks while at the same time improving the livelihoods of forest dependent people as well as national incomes.

In order to address the livelihood imperatives as well as to mitigate adverse effects of climate change, there is need to identify both improved and traditional practises and/or technologies used for the restoration of degraded forests, woodland areas and parklands of the Sahel region and the rest of SSA. Chirwa and Larwanou 2017; Chirwa et al., 2015a; 2015b; Maisharou et al., 2015 report on some of the approaches for restoration of such landscapes. For such restoration to succeed, it is important to develop an understanding of how various factors that cause land and forest degradation, in addition to 
identifying relevant practices and technologies that are already employed in addressing such challenges. The technologies must include both traditional forest management practices and new tree planting approaches. The socio-economic benefits associated with such technologies that have the potential to promote both forest land and/or restoration have to be established, together with the institutional frameworks that could support their implementation, including supporting policy and regulatory mechanisms and all in the broader context of sustainable forest management when dealing with forest resources, and approaches farmers use for managing trees outside forests like farmer managed natural regeneration in some agroforestry systems.

A key glaring shortcoming in Africa in achieving SFM in the different forest types is the absence of platforms for sharing relevant knowledge and experiences as well as successful stories in this regard. In order to address this gap, the African Forest Forum in collaboration with the African Union Commission, the Network for Natural Gums and Resins in Africa, the Centre for Sustainable Development-University of Ibadan, and the Forest Research Network for Sub-Saharan Africa, and with financial support from the Swiss Agency for Development and Cooperation (SDC) and the Swedish International Development Cooperation Agency (Sida) organized a very successful scientific workshop on the theme Forests, people and environment; some perspectives from Africa. The workshop was structured under the sub-themes: rehabilitation of degraded lands using trees; managing forests in the context of climate change; forest governance, marketing and trade in forest products; and socio- economic issues in forestry. This event was organized as Pre-XIV World Forestry Congress workshop on 4 to 5 September 2015 in Durban, South Africa, just before the XIV World Forestry Congress. The World Forestry Congress took place in Africa for the first time in its history from 7 to 11 September 2015 in Durban, South Africa following the XIII WFC held in Buenos Aires, Argentina, in 2009. The workshop brought together African forestry stakeholders including those from national governments, civil society organizations, academia and research; in addition to important groups like youth and women. They discussed important trends relevant to the African forestry sector with a view to enhancing the roles of forests and trees in national economic development and poverty alleviation; 
improving food security and nutrition and; enhancing environmental stability and other forest values.

This special issue presents some of the research findings shared at the pre-congress workshop; and this paper provides some highlights from the presentations.

\section{Rehabilitation of degraded lands using trees}

In this issue, the main drivers of land degradation identified include the following: population growth; agricultural expansion; climate variability and energy needs. On the positive side, a number of good practices and experiences for managing the forests, woodlands and parklands exist and were identified. Some of the approaches used in natural regeneration include complete coppice; coppice with standards and selective cutting; pollarding, pruning and lopping; all found to be the predominant form of restoration in dry forests and woodlands of southern Africa. Artificial regeneration through woodlots or farm forest is prioritized for out-growers in Uganda, while energy production in Rwanda and reforestation of bare hills in Ethiopia are the priority action areas for this approach. Enclosures are prevalent in livestock farming areas where they are used to encourage rehabilitation of grazing land, for example in the Tigray in Ethiopia. Also, in the Sahel, enclosures together with different sustainable land management (SLM) practices are used to protect young growing trees. In East Africa enclosures are applied on degraded, generally open access land in many dryland areas, as a mechanism to promote natural regeneration. This is mainly for environmental rehabilitation and has resulted into very visible biophysical impacts on large parts of the formerly degraded lands (Chirwa and Larwanou, 2017; Chirwa et al., 2015b). There is also increased adoption of forest and tree management practices and technologies that have the potential to promote rehabilitation and/or restoration of degraded forests, woodlands and parklands. For example, assisted or aided regeneration is especially prevalent in the Sahel where indigenous tree species are planted (enrichment planting) or seedlings from natural sources are protected and managed by land owners known as farmer managed natural regeneration (Larwanou et al.; 2006; Larwanou and Saadou, 2011). Research in this issue 
indicates that age-old systems such as native non-browse shrubs in Ethiopia are important in that they facilitate regeneration of late successional trees species (Abiyu et al., 2017).

Further, farmer managed natural regeneration is also common in some countries like Niger, with very significant gains having been reported in southern parts of the country (Haglund et al., 2011). Opportunities also exist for promoting forest restoration through tree planting for carbon markets in rural communities in the form of community-based REDD+ initiatives for sustainable forest management. Agroforestry is also recognized as an important avenue for rehabilitation of degraded areas, especially to improve soil fertility and soil conservation, and also in enhancing ecosystems services.

Natural regeneration through active involvement of local communities supported by enabling policies such as clear forest, tree and land tenure is the most successful and promising option for restoration of the large areas of degraded land. However, while policies promoting participatory natural resource management are in place in most African countries, implementation of these regeneration activities have mostly taken a pilot project based approach, with few strategies for up scaling by the governments. In addition, enabling policies for community based approaches, including clear cut land tenure and equitable benefit sharing, are still very much wanting in some countries, and they constrain investments in developing, managing and using these resources; thus impairing their full contribution to rural livelihoods, poverty alleviation and national economic development.

\section{Managing forests in the context of climate change}

The last two decades have seen considerable attention paid in Africa to issues of climate change with respect to forests and trees, and the people who depend on them (see Chidumayo et al., 2011; Chirwa et al., 2015a, 2015b; Maisharou et al., 2015, Kitula et al., 2015a, 2015b). Many countries now include mitigation and adaptation measures in their forest policies, plans and activities (Kojwang and Larwanou 2015a, Kojwang and Larwanou 2015a, 2015 b). There has also been noticeable awareness and adoption of various initiatives like Reducing Emissions from 
Deforestation and Forest Degradation (REDD+) in many African countries, however less so on Clean Development Mechanism (CDM) initiatives in forestry. The challenge for forest management is therefore how to add and operationalize the objective on carbon sequestration (i.e. introduce a climate change component) in forest management plans, while not constraining the supply of other equally important forest products and services from all forest types. In addition, this issue highlights the concerns about the implications of strategic and practical steps taken in the context of forestdependent communities (Ofoegbu et al., 2017). The integration of local socio-economic vulnerabilities and forest-based climate change intervention initiatives are projected to enhance resilience and adaptation to climate variability and climate change.

In this issue the gaps in knowledge and methodological inconsistencies in understanding the quantification of carbon, especially soil carbon, arising mostly from model development are highlighted, including the associated with sampling errors, measurement errors and model misspecification (Handavu et al., 2017). For soil carbon measurements there is need to develop a standardized framework for sampling forest soils. Also with regard to knowledge gaps, the review emphasized the need for having an integrated understanding of carbon storage dynamics and the associated implications of land-use practices and land cover change in major carbon pools in dry forests and woodlands as a precursor to the improved carbon accounting. Further, there is the need for in-depth understanding of the link between socio-economic and local forest utilization attributes, and how these can inform better management of the forests and woodlands in ways that can enhance ecosystem functioning and ecosystem service provision, including carbon storage. This is especially important with the introduction of forest carbon trading as an incentive to forest and tree farming in Africa.

Also reported in this special issue is an evaluation of the expected returns by investors in these resources made for products from various tree species at their rotation age (the time of their harvesting) and taking into account forest carbon offsets in the compliance and in the voluntary 
markets as explored in Eastern Africa. The observed decline in the price of carbon to very low prices will no doubt constrain investments that could come with initiatives like Reducing Emissions from Deforestation and forest Degradation (REDD+). This is already creating challenges to forest managers on how to optimize the joint production of timber, enhance carbon sequestration, and possibly produce other non-timber benefits (Oeba et al., 2017; Olschewski and Benitez 2010). In this issue, it was demonstrated that overall, revenues expected to be realized from sale of carbon were lower than those from sale of wood. Consequently, forest carbon prices in voluntary and compliance markets need to be competitive and attractive in order for the forest owners to give up some timber returns in exchange of carbon income or modify forest management regulation in order to increase carbon sequestration (Oeba et al., 2017).

The effect of climate change on forest species was also reported on. The importance of forests in Africa cannot be over emphasized with respect to biodiversity, consumptive (food, fibre, fuel, shelter, medicine) and non-consumptive use (ecosystem services and the economically important tourism industry). Forest fragmentation as a result of human disturbances, such as tree logging and conversion of natural forests to agricultural lands, alters the ecological processes and changes the floristic composition of plant communities (Paré et al. 2009; Clark and Covey 2012 in Assogbadjo et al., 2017)). Since climate is a primary determinant of species distributions and ecosystem processes, many communities will be vulnerable to the effect of climate change on forest tree species (Opere et al., 2011). Certain ecosystem types will be particularly vulnerable: ecotones (transition areas between different ecosystems, with high species and genetic diversity), which are important for adapting to climate change are highly threatened by climate change especially in semi-arid drylands prone to desertification. The woodlands and savannas have been reported to be also very vulnerable where species diversity and endemism are particularly high and where there is an extraordinary threat of loss of species or habitat. In this special issue some insights on these aspects are given from a study of one tree species that assessed how disturbance and climatic variability impact the population structure of a threatened species Afzelia Africana, a tree species that is widely distributed in West Africa 
(Assogbadjo et al., 2017). The findings demonstrated that climatic variability, compared with disturbance gradient, exhibited a greater effect on species population fitness; while tree density, basal area and tree height were mostly influenced by the climatic variability; and so was the regeneration density of the species.

From many of the workshop presentations, discussions and literature, it is increasingly becoming apparent in many countries that forest-related development and economic undertakings, new policies, research and education programmes, conservation efforts, etc., tend to be conceived with some justification on how they take into account climate change mitigation and adaptation. While this may be positive in that it puts a new focus on forests, and attracts previously unheard of amounts of funds for "forest-climate" initiatives, it also has drawbacks. The most problematic one is that this focus on climate change takes attention away from the enormously important current and potential roles of sustainably managed forests and trees as drivers of economic development and poverty alleviation or, from the much more immediately important needs of conserving forests for biodiversity protection and hydrology enhancement. However, there are many positive signs today that funders of various REDD+, carbon credit and climate mitigation programmes realize that without putting economic and "conventional" conservation effects in the foreground, it will not be realistic to achieve major positive impacts on climate through "forest-climate" programmes. To this end, there is increasing recognition that REDD+ can bring climate benefits not only through adaptation and mitigation activities but also beyond carbon. So, in designing and implementing climate change strategies and plans, this dual character of benefits needs to be taken into account so that non-carbon benefits are also incentivized.

\section{Increased participation of the private sector and civil society in forest management}

The key players in forestry business are national governments, local communities, the private sector and civil society. Presently there is an observed increasing involvement of rural communities, as small holder tree farmers and in forestry issues, as well as the private sector and civil society; this could significantly influence how forests are owned and managed in future. 
The private sector is especially important in harvesting of timber from natural forests as well as in establishment of forest plantations. The sector is also prominent in processing of timber, its marketing and trade. It is also important in the harvesting, processing and marketing of non-timber forest products. These attributes give the private sector a central role to play in the future of sustainable forest management and use in Africa. The private sector has also a key role in the governance and use of these resources and establishing responsible relations with local people and communities. However, in many countries, the sector continues to be characterized by many uncoordinated small players, does not feature in national plans, lacks investment and a champion for its cause, and remains largely informal. However, in some countries big private investments in commercial forestry enterprises are being promoted through public- private partnerships (Chirwa et al., 2015c).

National governments handle forestry work through their forestry authorities/departments. These have important roles of oversight, policy and law formulation and implementation, and setting in place an enabling environment for sustainable forest management so that rural people/local communities and the private sector can invest in forests and trees and benefit from their products and services. National governments are also major owners of natural forest resources (Dlamini et al, 2015).

The civil society organizations are emerging as key players in forestry; they fill some gaps left by national governments in Africa when they move away from doing forestry business to becoming custodians of policy and enforcers of forest laws and regulations. More specifically nongovernmental organizations (NGOs) are also a very crucial link to local communities, who are also increasingly owning and managing these resources. They also feature very prominently in handling new issues in forestry, as can be seen in their visibility in facilitating and undertaking, with local communities, REDD+ activities and community based forest management. Civil society organizations also facilitate many activities related to marketing and trade of timber and non-timber products (Nhantumbo and Camargo, 2015).

Unfortunately their effective coordination within the forestry sector, is in many countries not adequate, in addition to the required support (in terms of capacity and skills building and finances 
etc.) to deliver on their mandates.

The local communities are at the core of local governance, provided they have secure tenure, access rights, responsibilities and resources. They are increasingly taking on responsibilities for forest and woodland management through devolved rights and responsibilities. Rural people use tree and timber products for many diverse reasons, and are increasingly entering the market for tree and timber products. Rural people are organizing themselves into, for example, associations and village committees, in order to take on their resources rights and responsibilities. However, this comes with several challenges; including how to strengthen individual farmers as groups or associations so that their voices can be heard, especially in soliciting credit for investment, product value addition, marketing of the produce, and lobbying for favorable policies. Further, the situation becomes even more complicated when consideration is given to supply of quality germplasm for tree planting to dispersed farmers, putting in place economically feasible harvesting and processing mechanisms for wood from individual farms where trees are interspersed with agricultural crops, livestock enclosures and human dwellings.

So far, studies on the achievements of involving local communities in participatory forest management practices (PFM), specifically in terms of contribution to forest conservation, tree plantation growth and management, and the improvement of standards of living of local populations, have been poorly documented. Most studies highlight the problems of poor participation of local communities due to either poor initial planning or subsequent lack of clear benefit sharing mechanisms (Senganimalunje et al., 2015; Phiri et al., 2012). In a study from Benin on the reforestation in WariMaro Forest Reserve, through this approach in order to improve forest productivity and reduce human pressure (Gandji et al., 2017), the findings showed that plantation establishment did not succeed well. However, plantations established with exotic species exhibited better structural characteristics than those planted with native species. In addition, the perceptions of the local communities on the PFM varied among respondents and were more linked to their socio-economic aspects rather than 
biological ends. On the other hand, a study from Oyo State Nigeria (Azeez et al., 2017) demonstrated the benefits of the taungya system in the promotion of tree planting and forest conservation.

\section{Marketing and trade in forest products}

Africa has a dominance of "energy" wood products - fuelwood and charcoal, on its menu that makes about $76 \%$ of the wood products it consumes. Since they are mostly consumed outside than inside the formal market economy, no accurate statistics on them are recorded. With the exception of firewood and charcoal which are locally produced, Africa consumes more processed wood products than it produces. A key development agenda in Africa relates to regionally integrate its national economies, with one of the expectations being that this will increase trade across national borders and also across its sub-regions. The logic is that through such intra-African trade there will be generated economic activities that will bring socio-economic growth in the individual countries, the sub-regions and the continent as a whole. The forestry sector has therefore a role to play in this. Available records on intra-African trade in forest products indicate that the volumes traded have been very small (Chipeta and Kowero, 2015; Maisharou and Larwanou 2015). Africa's wood industries have a very high proportion of informal and small scale operators and few of them are players at the sub-regional, continental or global levels. Further, the sub-regions that are rich in natural forests (Central and West) have a weak developed wood processing industry; in fact there is virtually no paper or paperboard manufactured in these two sub-regions despite abundance of wood raw material for the same.

There are potentially big unrecorded, and possibly very significant, illegal sales of forest products across national borders (Chipeta and Kowero, 2015). While it is right to condemn illegalities in such trade, it is also important to understand how this profitable trade is evolving, its contribution to socioeconomic development, and how it could be formalized and well organized so that it contributes to broader policies of economic integration in Africa, where trade is key.

Africa's largest wood processing industry is charcoal production and trade, and it is already larger than paper and paperboard manufacture. Scanty attention is paid to this reality. Charcoal is a staple 
energy source for millions of Africans in urban and semi-urban areas and is slowly creeping into rural areas as well. There are no significant visible alternatives for charcoal for the majority of the people who use this energy in the short to medium term. The key problems with its production and trade ate its disorganised and destructive nature. Africa had better make the charcoal sub-sector "a legitimate, dynamic and fully legalised, mainstreamed, modernised activity - anchored on sustainable raw material provision and its production and trade in it better organised".(Chipeta and Kowero, 2015)

In this special issue, the role of non-timber forest products in the savanna and tropical moist forests of Ghana and Nigeria, respectively in generating incomes for the rural and vulnerable communities are highlighted. For instance, in Ghana and indeed the whole savanna belt of West Africa, shea tree (Vitellaria paradoxa C. F. Gaertn.) is an important wild and naturally growing indigenous species. The shea industry has been identified as a potential contributor to the economic empowerment of women (Kent and Bakaweri 2010; Kent et al. 2014; Kombiok and Agbenyega 2017). However, commercialization of shea butter has been reported to be hampered by poor financing mechanisms and inadequate production and marketing capital for shea butter processing (Kombiok and Agbenyega 2017). The study assessed the financing schemes and the financial delivery mechanisms available for the production and marketing of shea butter in the Northern Region of Ghana with a view to determining the impacts on its processing and marketing. As observed in other studies, this study found that when there was some form of external financing extended to them, shea butter producers do not have control over the sale and price of their products. The women, who are the main producers, perceived that the existing contractual financial arrangements did not allow them to enjoy high financial returns.

While shea butter and a few other Non-Timber Forest Products (NTFP) like Adansonia digitata can be commercialised; the general perception on NTFPs products is that they are non-attractive as a source of good income due to the nominal prices offered along their whole marketing chain (collection, processing and selling). Additionally, there are other factors that affect full 
commercialization such as resource distribution within the forest, seasonal and annual fluctuations in quantity and quality of NTFPs production which often lead to overexploitation (Akinnifesi et al., 2006; Chirwa et al., 2008). Finally, as alluded by Kombiok and Agbenyega (2017), the relationship between collectors and traders is exploitative and therefore does not move the custodians of the resource out of poverty. The study by Amusa et al (2017) investigated the market constraints and socio-economic factors influencing trade in five top priority NTFPs within the tropical lowland rainforests of southwest Nigeria. Findings similar to those obtained in Ghana by Amusa et al (2017) demonstrated the existence of several market constraints including: seasonality; insufficient and poor transportation services; poor road network; lack of storage facilities; lack of training or skills for product transformation; and lack of market information; they all combine to adversely influence trade in NTFPs. In both cases improvements in commercialization of NTFPs can be achieved through good and effective policies that promote empowerment of the relevant local communities through microfinancing, skills development on value addition and marketing of the products.

\section{Conclusion}

The studies in this issue underscore the importance of forests to the livelihoods of African people both in the rural and urban areas through the ecosystem services highlighted. The studies also highlight the need to recognize traditional forest management practices; institutional frameworks as well as ecological manipulation of the forest species in order to contain degradation through forest and tree restoration and promote favourable mitigation and adaptation approaches to climate change. The studies call for increased research in order to understand the ecological processes involved during forest restoration following forest disturbance and for the standardization of measurements for carbon as well as securing measures to include forest carbon in the menu of other forest products in order to increase the viability of trade in forest carbon. The need to rapidly increase the pace and scope of timber and non-timber products processing and trade within Africa and between Africa and the rest of the world is also emphasised. Finally, poor participation in the management of the forest resource, weak policies on land tenure, and lack of capacity and skills for value addition and marketing have 
to be addressed in order to encourage local communities to become viable custodians of the forest resource for future generations.

\section{References}

Abiyu A, Teketay D, Glatzel G, Aerts R, Gratzer G. 2017. Restoration of degraded ecosystems in the Afromontane highlands of Ethiopia: comparison of plantations and natural regeneration. Southern Forests 79. DOI: 10.2989/20702620.2016.1254917.

Akinnifesi FK, Kwesiga F, Mhango J, Chilanga T, Mkonda A, Kadu CAC, Kadzere I, Mithofer D, Saka JDK, Sileshi G, Ramadhani T, Dhliwayo P. 2006. Towards the development of miombo fruit trees as commercial tree crops in southern Africa. Forests, Trees and Livelihoods 16, 103-121.

Amusa TO, Jimoh SO, Azeez IO. 2017.Socio-economic factors influencing marketing of non-timber forest products in tropical lowland rainforests of south-western Nigeria. Southern Forests 79. DOI: $10.2989 / 20702620.2016 .1255411$.

Assogbadjo AE, Mensah SM, Glèlè Kakaï R. 2017. The relative importance of climatic gradient versus human disturbance in determining population structure of Afzelia africana in the Republic of Benin (West Africa). Southern Forests 79. DOI: 10.2989/20702620.2016.1255406.

Azeez IO, Popoola L, Shulamite IO. 2017. An assessment of the forest regeneration potential of the taungya system of farming in Oyo State, south-western Nigeria. Southern Forests 79. DOI: $10.2989 / 20702620.2016 .1255425$.

Chipeta ME, Kowero G. 2015. An overview of intra-African trade in forest products: opportunities and challenges. International Forestry Review Vol.17(S3): 114-125

Chirwa PW, Larwanou M. 2017. Overview of restoration and management practices in the degraded landscapes of the Sahel and dryland forests and woodlands of East and southern Africa. Southern Forests 79. DOI: 10.2989/20702620.2016.1255419. 
Chirwa PW, Mamba S, Manda SM, Babalola FD. 2015. Assessment of settlement models for engagement of communities in forest land under claim in Jessievale and Roburna communities in Mpumalanga, South Africa. Land Use Policy Journal 46:65-74.

Chirwa PW, Syampungani S, Geledenhuys CJ. 2008. The ecology and management of the miombo eco-region for sustainable livelihoods in southern Africa: The case for non-timber forest products. Southern Forests 70(3): 237-245.

Chirwa PW. Larwanou M, Syampungani S, Babalola FD.2015a. Management and Restoration Practices in Degraded Landscapes of Eastern Africa and Requirements for Up-Scaling. International Forestry Review 17(S3): 20-30

Chirwa PW, Larwanou M, Syampungani S, Babalola FD.2015b. Management and Restoration Practices in Degraded Landscapes of Southern Africa and Requirements for Up-Scaling. International Forestry Review 17(S3): 31-42.

Dlamini C, Larwanou M, Chirwa PW. 2015. A brief overview of the capacities of public forest administrations in climate change work in the moist forests countries of Sub-Saharan Africa. International Forestry Review 17 (S3): 53 - 66;

FAO 2008. Understanding forest tenure in Africa: opportunities and challenges for forest tenure diversification. Forest Policy and Institutions Working Paper Number 19.

Gandji K, Salako VK, Assogbadjo AE, Orékan VOA, Glèlè Kakaï RL, Sinsin BA. 2017. Evaluation of the sustainability of participatory management of forest plantations: the case study of Wari-Maro Forest Reserve, Republic of Benin (West Africa). Southern Forests 79. DOI:

$10.2989 / 20702620.2016 .1255409$.

Haglund E, Ndjeunga J,Snook L, Pasternak D. 2011. Dry land tree management for improved household livelihoods: Farmer managed natural regeneration in Niger. Journal of Environmental Management 92:1696-1705 
Handavu F, Chirwa PW, Syampungani S, Larwanou M. 2017. A review of carbon dynamics and assessment methods in the miombo woodlands. Southern Forests 79. DOI:

$10.2989 / 20702620.2016 .1277643$.

Hosonuma N, Herold M, Sy VD, Fries RSD, Brockhaus M,Verchot L, Angelsen A, Romijn E. 2012. An assessment of deforestation and forest degradation drivers in developing countries. Environmental Research Letters 7(4):4009

Kent R, Bakaweri C. 2010. Mechanisms to ensure participation in shea value chain: A case study of two interventions in Northern Ghana. Trade and Markets Division of Food and Agriculture Organisation (FAO) Workshop on Institutional innovations and policy interventions in support of small holder markets participation held on 3-4 June 2010 Rome, Italy.

Kent R, Bakaweri C, Poole N. 2014. Facilitating entry into shea processing: a study of two interventions in northern Ghana. Food Chain 3: 209-224.

Kitula RA, Larwanou M, Munishi PTK, Muoghalu JI, Popoola L. 2015a. Climate vulnerability of biophysical systems in different forest types and coastal wetlands in Africa: a synthesis. International Forestry Review 17(S3): 67-77

Kitula RA, Larwanou M, Munishi PTK, Muoghalu JI, Popoola L. 2015b Climate vulnerability of socio-economic systems in different forest types and coastal wetlands in Africa: a synthesis. International Forestry Review 17(S3): 78-91

Kojwang, HO, Larwanou M. 2015. Forestry-related input into relevant policies at the Aregional and global levels: An African perspective on climate change. International Forestry Review 17(S):92-102 Kojwang HO, Larwanou M. 2015.An overview of nationally appropriate mitigation actions (NAMAs) and national adaptation programmes of action (NAPAs) in Africa. International Forestry Review 17(S3): 103-113 
Kombiok E, Agbenyega O. 2017. The characteristics of financing arrangements for the production and marketing of shea (Vitellaria paradoxa) butter in Tamale in the Northern Region of Ghana. Southern Forests 79. DOI: 10.2989/20702620.2016.1255403.

Larwanou, M., Abdoulaye, M and Reij. 2006. Etude de la Régénération Naturelle Assistée dans la région de Zinder (Niger) : première exploration d'un phénomène spectaculaire. C International Resources Group, Washington DC. 67p.

Larwanou, M, Saadou, M. 2011. The role of human interventions in tree dynamics and environmental rehabilitation in the Sahel zone of Niger, Journal of Arid Environments 75 (2011) 194-200

Luoga EJ, Witkowski ETF, Balkwill K. 2000. Subsistence use of tree products and shifting cultivation within a Miombo woodland of Eastern Tanzania, with notes on commercial uses. South Africa Journal of Botany, 66, 72-85.

Maisharou A, Chirwa PW, Larwanou M, Babalola FD, Ofoegbu C. 2015. Sustainable Land Management Practices in the Sahel: Review of Practises, Techniques and Technologies for Land Restoration and Strategy for Up-Scaling. International Forestry Review 17(S3): 1-19.

Maisharou A, Larwanou M. 2015. Market potential of non-wood forest products in the Sahelian countries. International Forestry Review 17(S3): 125-135

Nhantumbo I, Camargo M. 2015. REDD+ for profit or for good? Review of private sector and NGO experience in REDD+ projects. Natural Resource Issues, No. 30. IIED, London.

Oeba VO, Larwanou M, Otor SCJ, Kung'u JB, Mbae MN. 2017. Growing common plantation tree species in Kenya for sale of carbon and wood supply: what is the best bet? Southern Forests 79. DOI: $10.2989 / 20702620.2016 .1274860$.

Ofoegbu C, Chirwa PW, Francis J, Babalola FD. 2017. Socio-economic factors influencing household dependence on forests and its implication for forest-based climate change interventions. Southern Forests 79. DOI: 10.2989/20702620.2016.1255420. 
Olschewski R, Benitez PC. 2010. Optimizing joint production of timber and carbon sequestration of afforestation projects. Journal of Forest Economics 16: 1-10

Opere A, Olago D, Chidumayo E, Osman-Elasha B . 2011. Climate change processes and impacts In Chidumayo E, Okali D, Kowero G, Larwanou M. (eds) 2011. Climate change and African forests and wildlife resources. African Forest Forum, Nairobi, Kenya, 18-33pp

Phiri M, Chirwa PW, Watts S, Syampungani S. 2012. Local community perception of joint forest management and its implications for forest condition: the case of Dambwa Forest Reserve in southern Zambia. Southern Forests: a Journal of Forest Science 74: 51-59.

Senganimalunje TC, Chirwa. WP, Babalola. FD, Graham MA. 2015. Does participatory forest management program lead to efficient forest resource use and improved rural livelihoods? Experiences from Mua-Livulezi Forest Reserve, Malawi Agroforest System 90: 691-710. 